\title{
THE FRESCOES OF BISERICA DOMNEASCĂ IN CURTEA DE ARGES, A REFLECTION OF THE MOSAICS FROM CHORA, CONSTANTINOPLE
}

\author{
Giugea Gheorghiţa Daniela \\ University Assistant, Phd, University of Piteşti, ROMANIA \\ giugeafloriceldaniela@yahoo.com
}

\begin{abstract}
The Reigning Church of Saint Nicholas in Curtea de Arges is one of the oldest monuments in Wallachia. It was built during the fourteenth century, following the pattern offered by the Byzantine churches, by a team of craftsmen, probably brought from the capital city of the Empire. With respect to the painting, most specialists have resembled it to the one in Chora, in Constantinople. The construction began under the reign of Basarab I and was continued by his son Nicolae Alexandru, considered to be, by many specialists, the true founder of the church; the painting was finished by Radu I and by Vladislav Vlaicu, the descendant of Nicolae Alexandru. In Curtea de Arges, there are a number of scenes that are quite rarely found in the painting of Byzantine churches, like The Census in front of Quirinius, considered to be the most beautiful mosaic in Chora, but also The Shelter of Confession etc. The painting in Chora is superior, due to the use of the mosaic technique that allowed the craftsmen to create special effects in what concerns light and colour. In the church from Curtea de Arges, we can find three paintings from three different historic periods, each one having its own special significance. The one dating from the fourteenth century provides the opportunity to establish the influences received, especially, from Chora, the place where the masterpieces of the art of Palaiologoi were created, but also from other Byzantine monuments built during that period.
\end{abstract}

Keywords: The Reigning Church of Saint Nicholas, Chora, painting, Byzantine art.

\section{INTRODUCTION}

Most of the experts that have studied the mural at Biserica Domnească achieved through several master painters' cooperation, noted some similarities with the style of the frescoes and the mosaics that decorate the Chora Church (Kahrye Djami), built between 1312- 1315 in Constantinople by Chancellor Teodor Metohites, a renowned scholar of the time (Moisescu, 2001, pp. 115-116). Apart from Chora, the painting from Curtea de Argeş is also related with the frescoes from Nagorično and Gračanica (Delvoye, vol II, p. 248), but also with those of other halidoms built in the Byzantine style.

Unlike other Byzantine buildings they resemble, Saint Nicholas Church is larger: the surface is $14.55 \times 23.50$ $\mathrm{m}$ and its height measured from the tip of the helm reaches $23 \mathrm{~m}$. It is divided into three spaces: the narthex, the nave and the altar; the narthex measures $2.80 \mathrm{~m}$ and the nave $11.80 \times 12.40 \mathrm{~m}$ (lonescu, 1963, $\mathrm{p}$. 
127). This is because, being raised in a royal ensemble, therefore as a church of royal court, the monument was meant to represent the state, hence the monumentality of the halidom.

It was Basarab I who started its construction, the founder of the state and the first founder of the church. He died in the capital city, Câmpulung, in 1352 being considered by some historians as follows: "Founder and organizer of the country, founder of the dynasty, victorious in wars and founder of holy places, Basarab fully deserves to be named great attributed to him both by the graphite from Curtea de Arges ("The great prince Basarab died in the year 6860 (1351 or 1352) in Campulung" (Musicescu, Ionescu, 1976, p. 17, Georgescu, 2002, p. 147-149) and by his son's tomb inscription: "Basarab the Great"; thus he will remain forever in the history of our people" (Giurescu, 2003, p. 302).

Asking himself why the votive painting of Basarab the Great misses from the church, Grigore lonescu (1986, p. 53) believes that the scene depicted above the inscription of the year of his death, representing a crowned character, a prince sitting in an armchair and assisting the construction of a building in progress, is in fact a representation of Basarab I himself, during whose reign the construction of the edifice began.

Nicolae Alexandru is considered the true founder of Biserica Domnească; he is portrayed in the scene Deisis (Prayer) in the central niche above the entrance to the nave. He died on 16 November 1364 and on the tombstone is written in Slavonic: "In the 16th day of November, slept the great and only ruler lo Nicolae Alexandru prince, the son of the great Basarab, in the year 6873 (1364) indiction 3. May his memory be eternal" (Giurescu, 2003, p. 308).

The painting was finished by Vladislav Vlaicu whose grave stone is kept in Biserica Domnească, and also by Radu I. The existence of complex compositions with numerous characters, the expressiveness and the elegance of the figures, the bright colours, the narrative character etc., all representing the style used in Palaeologan times (Oprescu, 2007, pp. 61-62).

The fact that the painting of Biserica Domneasca begun by Nicolae Alexandru (Ionescu, 1986, p. 53), was finished by Vladislav Vlaicu I and his wife Ana, represented in the nave is confirmed by the inscription discovered on the votive painting of the nave: "[†lo Vladislav, the one in Christ] blessed prince and [theonlyruler of Tara Românească, of Vidin and of the whole land of Vidin. "[†TheonlyladyKeraAn]a, in Christ, the faithful lady of Ţara Românească and of the entire [land of Vidin] ]" (Constantinescu, pp. 42-43).

Virgil N. Drăghiceanu (p. 4) is of the opinion that the one who completely finished the church, painting it, was Radu Negru-Voda, Vladislav's brother (Drăghiceanu, p. 4). However, Grigore lonescu believes that it is only an interpretation of the tradition, also claiming the idea that it was probably him who finished the painting (lonescu, 1940, pp. 32-35).

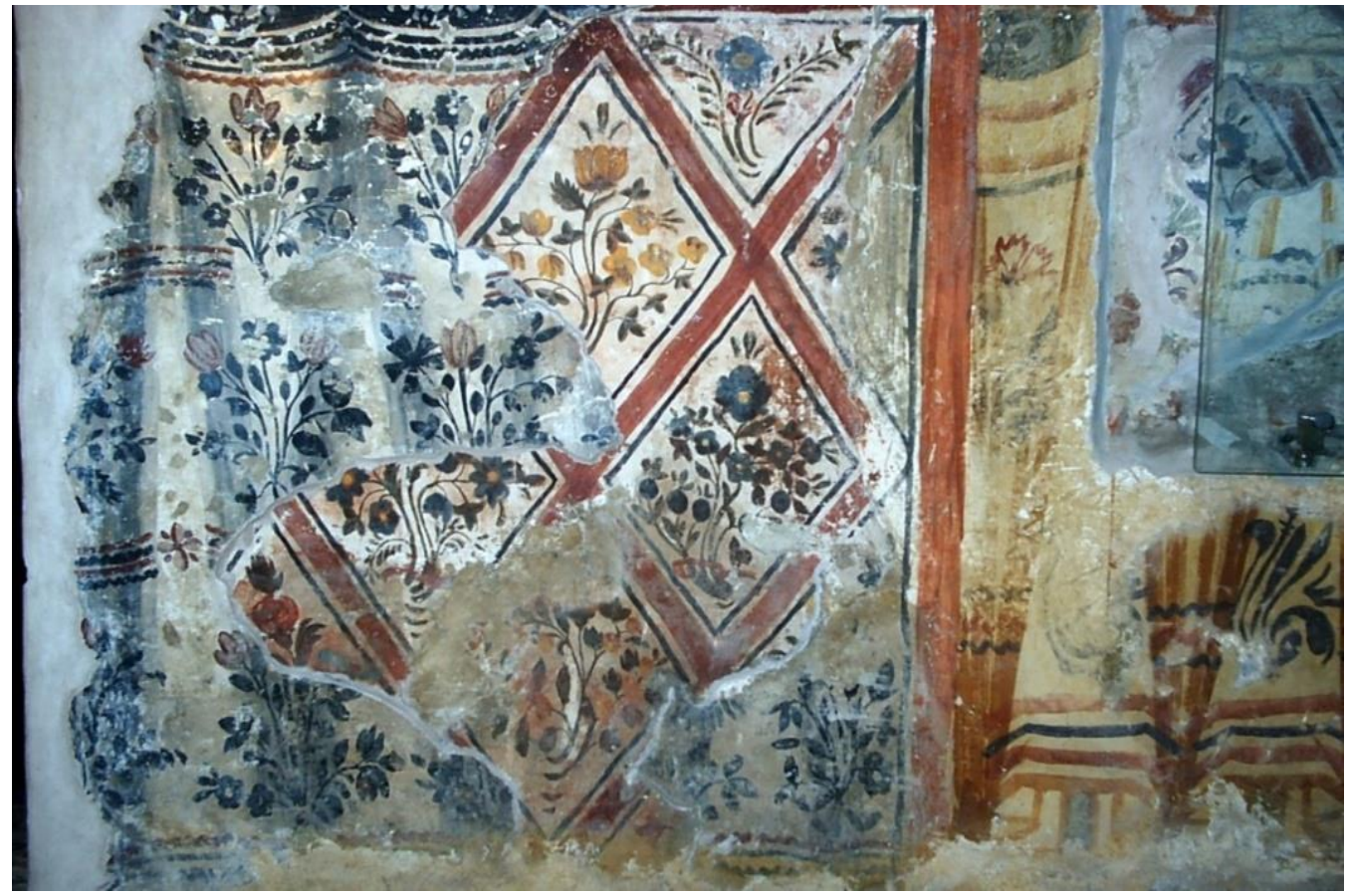

Fig. 1. Church Sf. Nicolae Curtea de Argeş. The three layers of paintings. Photo 2006. 


\section{THE ANALYSIS OF THE PAINTING OF THE CHURCH IN ARGEŞ}

\subsection{Generalization}

The painting of Curtea de Arges has a particular value since here one can notice the evolution of religious pictorial art since the second half of the 14th century until the mid-eighteenth century presenting "a real museum of religious painting" (Mihail, 1917-1923. p. 172). Here are highlighted three different paintings in point of style and epoch (Figure 1), the oldest dating from the 14th century, the second from 1750, attributed to Radu Zugravu and the third from 1827 attributed to the painter Pantelimon. The repainted frescoes either covered the initial ones from the 14th century or in the case of the painting in 1827 and the frescoes from the 18th century or they replaced damaged areas of the old painting.

Here's how I. Mihail appreciates the painting of Biserica Domneasca: "In the first painting we see the foundation of this art with us, in the second, its localization with us; the third and the last shows the decadence of this art; the other paintings, around 1847, have no artistic interest" (Mihail, p. 172).

\subsubsection{Style}

The style in which the frescoes from Biserica Domnească Sfântul Nicolae din Curtea de Argeş are made is influenced by the mosaics of Chora in Constantinople, corresponding to the maximum development during the Palaeologan era, but also by the paintings of other churches in the neighbouring countries like Serbia, Russia, Bulgaria or Macedonia. The essential features of the Byzantine art during the Palaeologan era include: the use of emotions and gestures to express feelings and emotions, the liveliness of the movements, the diversification of the characters' physiognomies, the prevailing of the narrative, the increase in the number of characters, topics inspired from the Gospel, the life of the Virgin and of the Saints and from the Prayer Anthem, the multiplying of the architectural scenery, the elongation of the characters' faces, using a richer chromatic scale adding shades such as: green, blue - gray, sulphurous yellow etc., lack of interest in the anatomical forms, emphasizing the sense of depth using the oblique line both for the backgrounds in architecture and in the landscape ones, the importance granted to the artists' personality etc. (Delvoye, pp. 219-221). These features of the art from the Palaeologan renaissance period are found in the frescoes in Curtea de Arges, too.

\subsubsection{Technique}

If the painting of Chora used the mosaic technique, the one in Curtea de Arges was executed in the fresco technique. Using the mosaic to decorate places of worship came to a climax during Justinian's time, those of Ravenna which depict the king with his retinue but also the Empress Theodora being famous. It was quite an expensive technique which demonstrated on the one hand the ruler's power and wealth and on the other hand the special qualities of the mosaic craftsmen. However, it had a downside - that it could not be executed on surfaces as large as the fresco. In the Palaeologan era the mosaic gradually gave in to the fresco, not only because the imperial treasury did not allow investments in this respect but also because of the inconsistency with the new aesthetic exigencies of the time. The Chora Church is among the few monuments decorated with mosaics in the era of Palaeologan renaissance but also a proof of the maturity of the style.

\subsection{The Iconography}

Throughout the evolution of the Byzantine art iconography has undergone transformations depending on the era. The organization of the interior space of the halidom was imposed at the same time with the early Byzantine art. Since the symbols used in the Early Christian art were no longer sufficient to express the religious sentiment and the number of believers was increasing it was necessary to replace symbols with images. Saint Gregory said: "Iconography is used in halidoms for those who do not know to read to be able to read at least the writing on the walls since they are not able to read the books"(http://www.catacombeleortodoxiei.ro/index.php/artaortodoxa/133-arhiva-revistei/cuprins/1162-arta ortodoxa-nr-02). Thus there were used scenes inspired by the Old and New Testaments and by the great feasts, too. The iconoclastic crisis led to the replacement of the human face with certain symbols but after the restoration of the veneration of icons a program was developed in the era of the dynasties of the Macedonians and the Comnenians, which was subjected to the dogma. It can be said that the painting was conceived as a pyramid, hierarchic scheme, with Christ on top of the pyramid representing the power, then the angels symbolizing soldiers and the saints the courtiers (Alpatov, vol. I., 1967, p. 236). This system was based on the concept of the king's unlimited power, the courtyard ceremonial etc., the predominance of the inscribed cross type church with central dome. 
The iconography of the church in Curtea de Arges corresponds to the Byzantine one where several scenes that occur less often in other churches are present: The Census in front of Quirinius, on the south wall of the nave or The Tabernacle with the offerings of the 12 representatives of the tribes of Israel existing in the apse of the altar (Florea, 2007, p. 77).

\subsubsection{The Painting of the Nave}

There are four episodes preceding the Nativity in the nave on the south wall: Mary and Joseph's journey to Bethlehem, accompanied by Jacob; The Census before Quirinius; King Herod asking the 3 Magi where Jesus was born; Herod asking the Pharisees and the scribes where Jesus was born. Also on this wall there are the following scenes: Jesus and the Apostles asleep in the Garden of Olives; Judas' betrayal; Mocking Jesus Christ; The Way of the Cross; The Multiplication of the Loaves; on the small dome near the place where the holy clothes are kept scenes from the life and Passion of Christ are shown, etc.

On the west wall of the nave there are: The Flight into Egypt; The Assumption of the Virgin Mary; The Transfiguration, the votive painting which shows Vladislav with his wife with the scale model of the church. There are also: The Massacre of the Innocents, The wedding at Cana, The parable of the wedding of the king's son, figures of saints etc.

The scenes are represented with deep feeling, such as Judas' kiss. Here observe movement and gesture that makes the character to get closer to Jesus Christ and expression of malice printed artist's figure.

The scenes are played with deep feeling, such as The Kiss of Judas. One can observe here the movement and the gesture made by the character to get closer to Jesus Christ but also the expression of malice printed by the artist on his figure.

\subsubsection{The Painting of the Steeple}

Pantocrator is presented on the steeple cupola repainted by Pantelimon in 1829 (Musicescu, Ionescu, 1976, p. 22); on the tambour the 12 apostles are painted.

The prophets' bodies are built solidly and their faces show a lot of aggressiveness. In simple attitudes the prophets' figures are also impressive and expressive. They are reminiscent of the Greek and Roman statues worshiped in temples (Mihail, p. 178).

\subsubsection{The Painting of the Altar}

In the altar, on its vault, the Mother of God is sitting on the throne with Jesus in her arms, supervised by St. John Chrysostom, St. Nicholas and the Archangels Michael and Gabriel. The representation is considered impressive by the classical purity of the figures, the nobility of the attitudes and the concentrated spirituality atmosphere they emit.

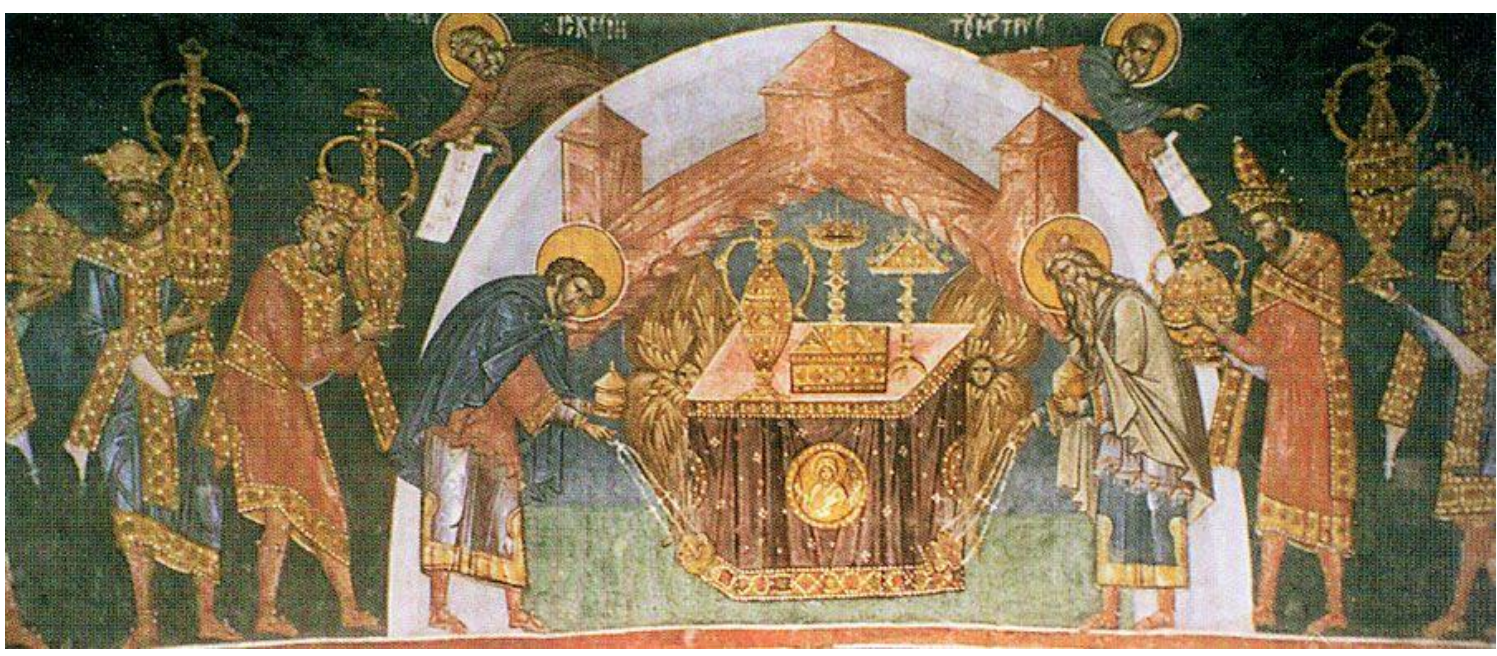

Fig. 2. The martyr dom tent. http://www.catacombeleortodoxiei.ro/index.php/stiri/132-arhivarevistei/cuprinspc/642-predici-77

One of the most original compositions of the altar is the Tabernacle (figure 2) painted on a frieze deployed on the whole surface of the apse representing the moment when, celebrating the twelve tribes of Israel in the tabernacle, Moses and Aaron come to bring their offering. The ornamental, pompous character, the richness 
of each character's garments is the only scene taken from the Old Testament bring very rarely represented in churches.

Other nine scenes about Jesus' appearances between Resurrection and Ascension, the Parable of the Ten Virgins, the Communion, the saint hierarchs: Cyril of Alexandria, Athanasius the Great, Gregory the Theologian etc. are also represented.

In the altar and the most part of the nave the draping is ample and edgy, synthetically following the anatomical form; the small interior folds contrast with the deep crimps of the plies; white, often doubled lines, shadows of a darker tone than the local colour and different colour brushstrokes draped increase the fragmentation of the draped surface (Barbu, p. 45).

\subsubsection{The Painting of the Narthex}

Scenes such as: Deisis, Presentation of the Virgin to the Temple, the Virgin's Engagement, St. Nicholas' Cycle, the Judgement, the Ecumenical Councils etc. are painted here.

\subsection{Analysis of the scenes from Biserica Domnească: Deisis, Census before Quirinius and Assumption of the Virgin}

In the narthex, the scene Deisis (Figure 4) which also comprises the portrait of the founder Nicholas Alexander wearing a crown made of lilies on his head is particularly important (Drăguţ, 2000, p. 100). He is represented alone because his wife was Catholic (Curinschi, p. 99). In the centre appears the image of Christ seated on a throne, with his feet resting on a kind of podium. He blesses with His right hand and with His left He holds a book on His knee. On the right is the Mother of God and on the other side is St. Nicholas, not John the Baptist as it frequently occurs. This aspect gives a special significance to the scene both historically and symbolically. The ruler and founder of the church does not appear holding the scale model of the church in the votive painting, as Theodor Metochites is represented at Chora and its size is greatly reduced as compared to the real one. It is a true gesture of allegiance to faith and his representation in such an image emphasizes the symbolic and historical value it gains.

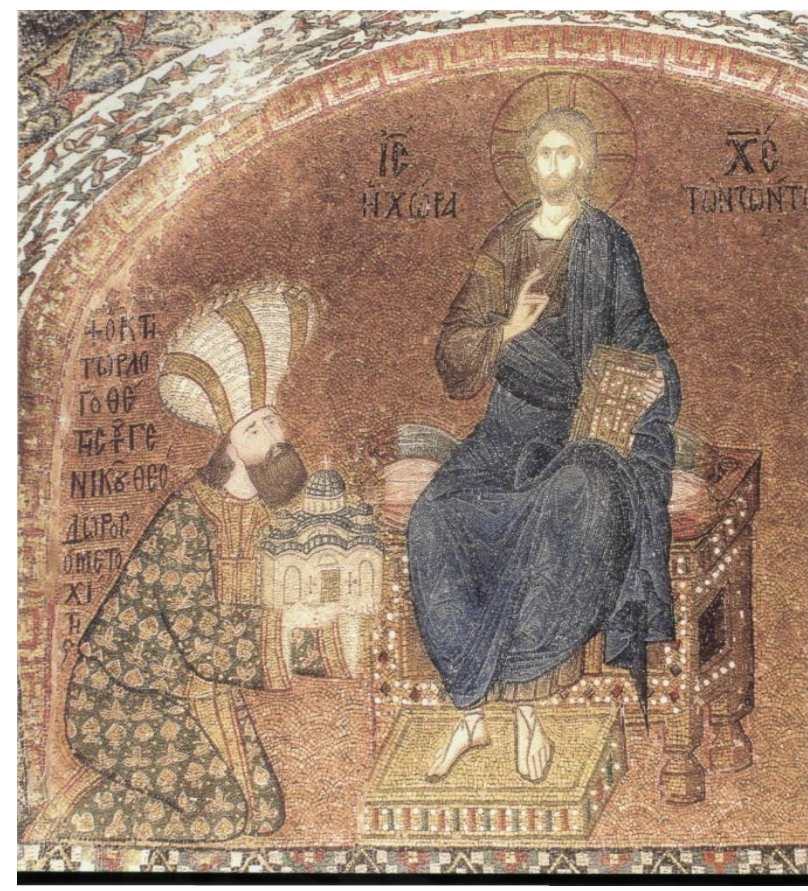

Fig. 3. Votive painting, Chora.

Reproduced from Akşit

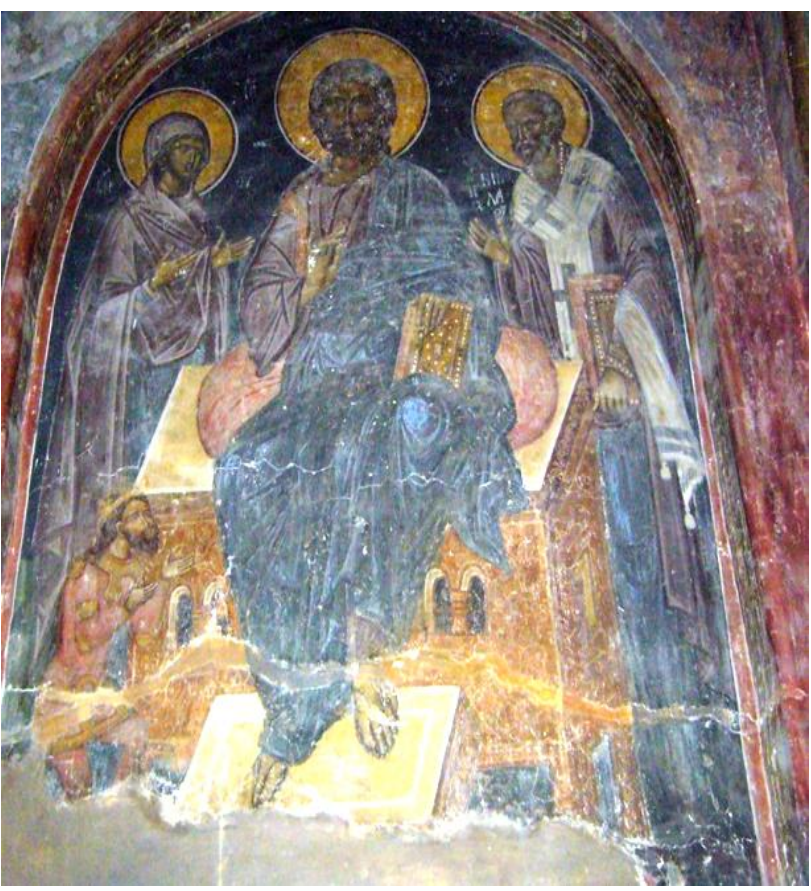

Fig. 4. Votive painting, the nave

Biserica Domnească

The founder of Chora wears sumptuous clothes and a turban on his head and while kneeling, he humbly offers Jesus the scale model of the church.

The mosaic from Chora is executed on golden background while the Deisis from Arges is presented on a blue background. 
The most important aspect of the influence of the painting in the church of Chora on that from Curtea de Arges is the existence of the two scenes rarely represented in the painting of the Byzantine churches: Census before Quirinius and The Tabernacle. Their technical and stylistic analysis provides clear evidence that the ones from Arges follow the model of the former thus contributing to a mature style but also to the further development of the painting in the Romanian churches.

The Census scene from Chora is considered unique in the Byzantine art and one of the most beautiful mosaics here (Akşit, 2003, p. 40). The governor sits on a throne to the left assisted by a soldier and in front of him there appears the group of characters embodying the official who notes the answers given by Mary accompanied by Joseph and another character.

Architectural elements of baroque complication appear, with many people whose attitudes are elegant and expressive (Delvoye, p. 224). Special qualities are given firstly by the technique of execution namely the mosaic (Grecu, 2011, pp. 454-455). The colouring is bright, made on gold background and blue and red are the predominant colours.

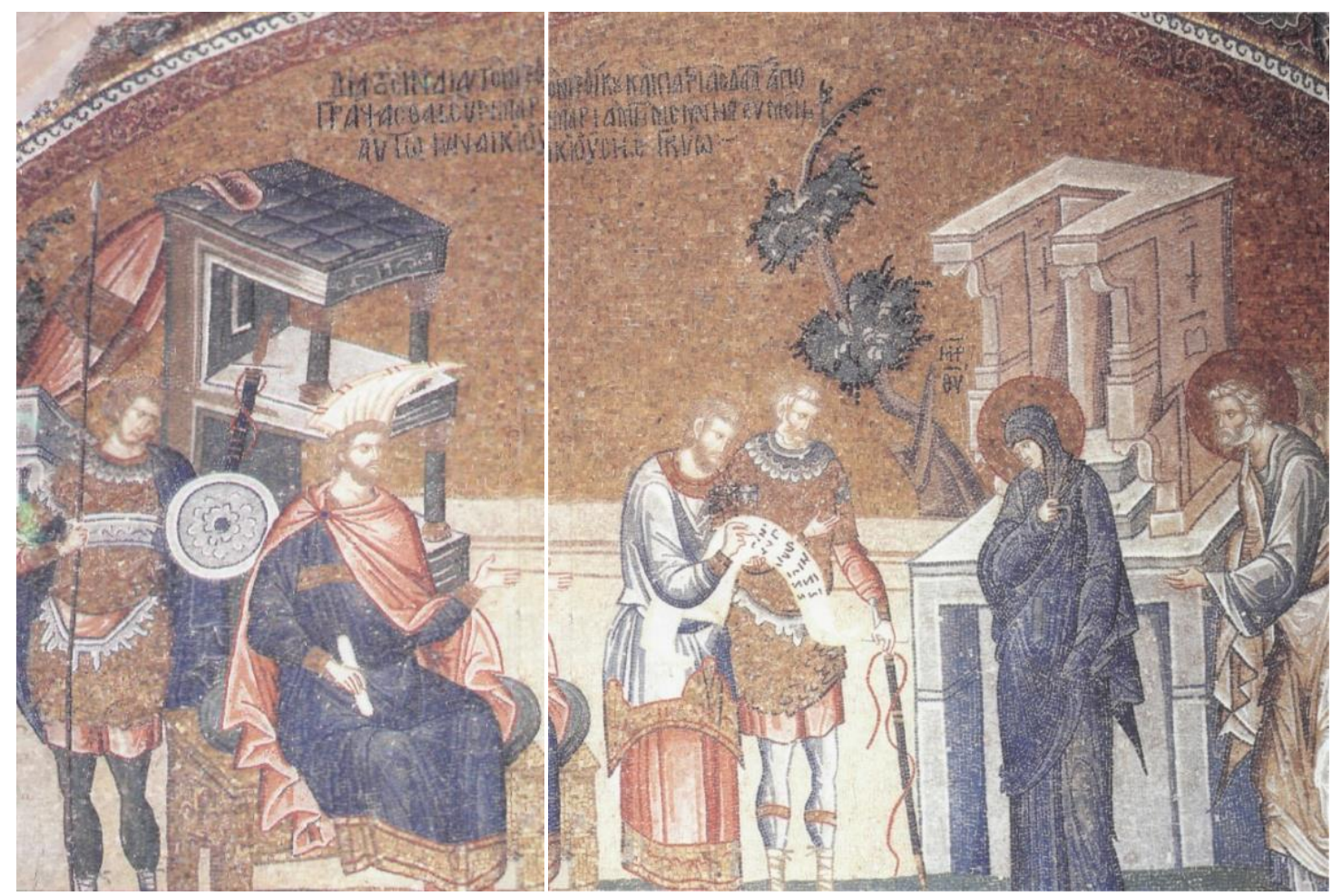

Fig. 5. Census before Quirinius. Mosaic from Chora.

\section{Reproduced from Akşit}

The fresco at Curtea de Arges representing the same scene (figure 6) was made by the first of the painters who contributed adorning the monument with paintings. Here the characters are rendered in a smaller space and signs of motherhood in what the Virgin is concerned are clearly accentuated as compared to Chora. The scene is more crowded, the characters are painted closer to each other as opposed to the other scene that is more airy with one of the characters missing. Architectural elements also appear in the composition of Arges and the figures appear more robust than the elongated ones shown in the similar mosaic from Chora. 


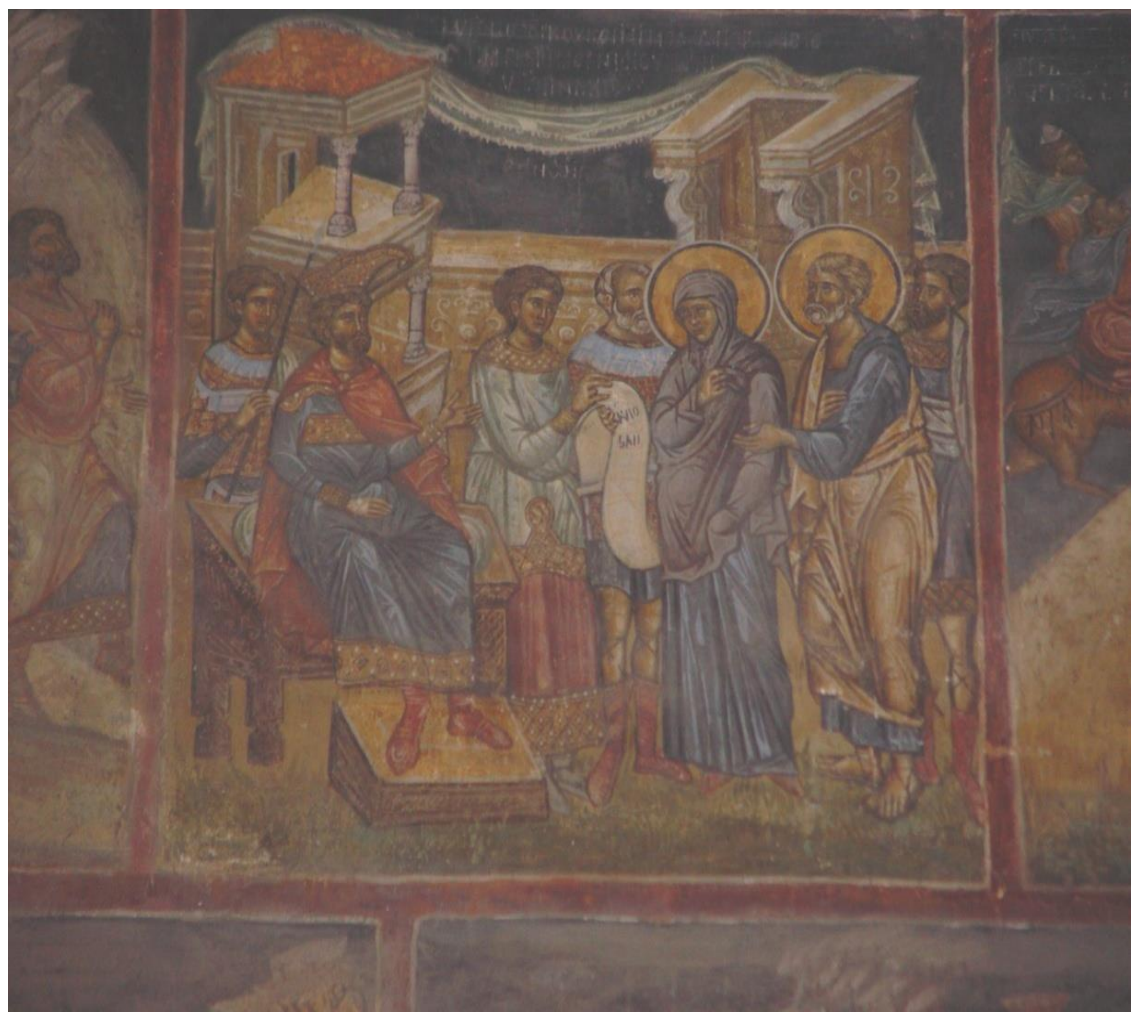

Fig. 6. Census, Biserica Domnească Sf.

Nicolae Curtea de Argeş. Photo Dorin Grecu.

The Assumption of the Virgin (figure 9) is shown on a large area. It appears lying on a bed surrounded by apostles and archangels and behind the bed Christ is accompanied by the cohort of angels receiving the soul of His mother. In front of the bed is also represented the attempted desecration which was ultimately punished. Above one can notice the face of the Virgin carried to the Kingdom of heaven by the angels and apostles flying into groups on clouds. To the left top of the painting the archangel Gabriel announces the death of Mary in beneath this scene Mary is represented while praying in the garden. On the right down side the Apostles are watching the tomb (Barbu, p. 54).

It is a unit composition, where one can see that the craftsmen who portrayed it sought to solve various technical problems preoccupying them, for example, to the left of the painting, there are attempts to harmonize the main colours through complementary tones. A wide range of colours and shades were used, from the grayed black of the background to the airy blue of the choir of angels and seraphims surrounding the slumbering with torches, singing (Figures 7,8 ). The scene was done with much feeling and warmth, including the attitudes and the expression of grief and pain that they gave to the figures of the women and of the apostles; one can see that they tried to give it a pronounced pathetic character (Mihail, p. 176).

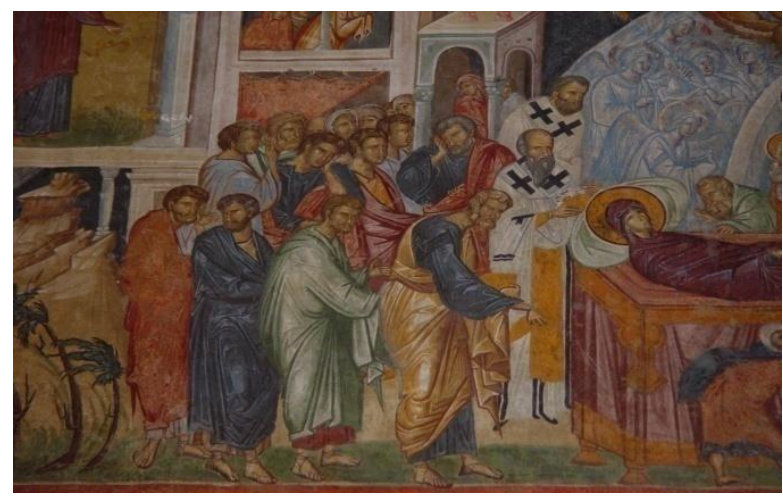

Fig. 7. Assumption. Detail.

Photo Dorin Grecu.

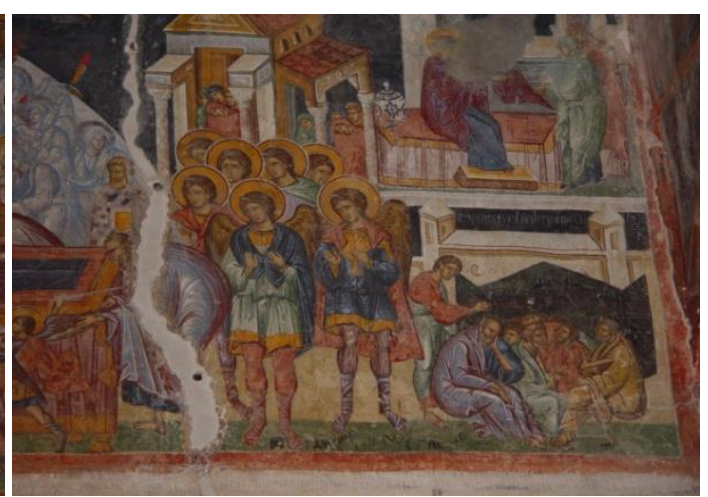

Fig. 8. Assumption. Detail.

Photo Dorin Grecu 
The painter who executed the scene in Curtea de Arges was not limited only to the central part taken from Chora, extending it by adding details to the left and right sides of the composition as well as the one in front of the bed. The backgrounds with the architectural elements are present both in the Byzantine mosaic and in the fresco at Arges. Christ's figure receiving Mary's soul is represented at Arges facing the image of the Mother while in Chora we see Him sitting, from the back, looking at Mary.

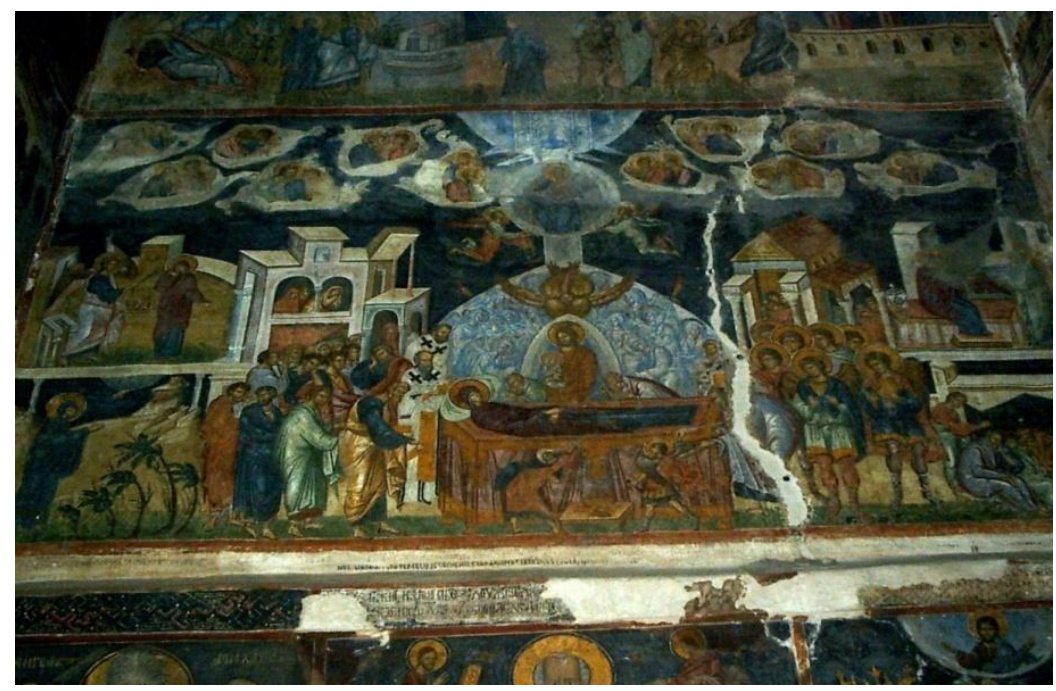

Fig. 9. Assumption of Mary.

Biserica Domnească Curtea de Argeş. Foto 2006.

The sadness and the pathetic character of the Chora mosaics representing the same scene of the Assumption of the Virgin (figure 10) inspired the painter who worked in Curtea de Arges. Although, the mosaic artist from Chora did not achieve a scene as complex as this, the faces' sensitivity, the delicacy and finesse of execution can be seen. It is one of the few scenes that were preserved in the nave since the Palaeologan era (Delvoye, p. 222).

The colours of the mosaics (Grecu, p. 456) are of outstanding beauty being likened to precious glazes. Bright colours such as cyan, lit red, gold-yellow, emerald green, purple etc. But also delicate halftones that emphasize primary colours are used. All are the expression of a high chromatic civilization (Lazarev, 1980, p. 16).

Due to the employed technical artifices "the Byzantine mosaics are flooded with light and they reflect light in the sacred space, in general" (Grecu, p. 455).

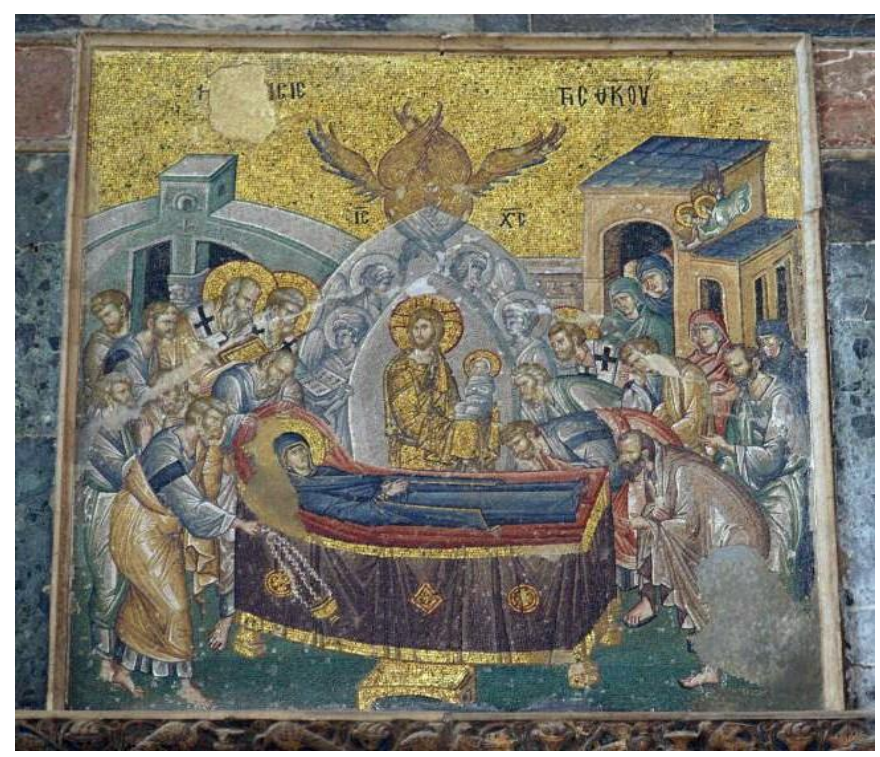

Fig. 10. Assumption of Mary. Mosaic.ChoraHttp://www.pemptousia.ro/2013/05/mozaicurile-maicii-domnuluide-la-manastirea-chora-constantinopol/. 


\section{CONCLUSIONS}

The painting of Biserica Domnească is purely religious resulting from the painters' care to comprehensibly present, especially to those who could not read, episodes from the life, teachings, miracles and sufferings of Jesus Christ, from St. Mary's life and legends, of the great Orthodox saints or of certain characters from the Old Testament. Thus the church presents almost all topics in Christian iconography (Barbu, pp. 52-56).

One way to achieve composition is crowding characters. The game of the gestures and movements is the main factor of consistency of the images: the rich man who has increased barns suddenly turns to the angel that admonishes him from above; the Holy Women also look from above at the archangel revealing the empty tomb etc. (Barbu, p. 49).

The special artistic qualities of the frescoes at Biserica Domnească of Curtea de Arges and the architectural ones caused the building to remain over time as a prototype, as a model and inspire successive generations (Ghica-Budeşti, p. 105). Most of the important churches in Wallachia until the XIV th century were inspired by Biserica Domnească: Vechea Mitropolie of Târgoviște (XV th century), pulled down by the French architect André Lecomte du Noüy, St. Demetrius church in Craiova, which had the same fate as the one in Târgoviște, Biserica Domnească in Târgoviște. Thus the Byzantine influence received especially from a monument located in the capital of Byzantium, built in the era of Palaeologan renaissance allowed on one hand the birth of a style through the first artisans who painted the church without being so highly ranked and on the other hand the development and uptake of Byzantine art on the Romanian territory. The frescoes in Curtea de Arges are not copies of the Chora mosaics. The iconographic theme well as the features of the Palaelogan style arisen at that time at the court of Constantinople were taken over, the scenes being adapted both to the space conditions and to the realities of that time existing in Ţara Românească.

\section{REFERENCE LIST}

Akşit, Ilhan, (2003) Le musée de Chora. Mosaïque et Fresque, Akşit Kültür ve Turizm Yayincilik.

Alpatov, Mihail, (1967), Istoria Artei, vol. I, Meridiane, București.

Barbu, Daniel,(1986), Pictura murală in Tara Românească în secolul al XIV-lea, Meridiane, Bucureşti.

Constantinescu, Nicolae, (1984)Curtea de Areş, 1200-1400. Asupra începuturilor Tării Româneşti, Editura Academiei Române, Bucureşti.

Curinschi, Vorona, Gheorghe,Istoria arhitecturii în România, Editura Tehnică, Bucureşti.

Delvoye, Charles,(1976), Arta bizantină, vol. II, Meridiane, Bucureşti.

Drăguţ, Vasile, (2000), Arta româneacă, Vremea, Bucureşti.

Drăghiceanu, Virgiliu N.,Curtea de Argeş. Călăuza vizitatorului monumentelor oraşului, Cultura Naţională, Bucureşti.

Florea,Vasile, (2007), Istoria Artei Româneşti, Litera Internaţional, Bucureşti - Chişinău.

Georgescu, George, (2002)Pictorul D. Norocea despre grafitul cu anul morţii marelui Basarab de la Curtea de Argeş, Argesis, Tom XI.

Ghica-Budești, N., Arhitectura Bisericii Domneşti. Originile şi influenţele, BCMI, anul X-XVI, 1917-1923.

Giurescu, C. Constantin, (2003)Istoria Românilor, vol. I, Editura All, Bucureşti.

Grecu, Dorin,(2011), Raportul lumină - culoare în pictura bizantină. Tipuri de lumină, Museum. Studii şi comunicări, X, Tiparg, Goleşti-Argeş.

Ionescu, Grigore, (1963), Arhitectura în România, Editura Academiei Republicii Populare Române, Bucureşti.

Ionescu, Grigore, (1986),Arhitectura Românească, Editura Tehnică, Bucureşti.

Ionescu, Grigore, (1940), Curtea de Argeş. Istoria oraşului prin monumentele lui, Fundaţia Pentru Literatură şi Artă "Regele Carol II", Bucureşti.

Lazarev, Viktor, (1980), Istoria picturii bizantine, Meridiane, Bucureşti.

Mihail, I., Pictura Bisericii Domneşti din Curtea de Argeş, BCMI, anul X-XVI, 1917-1923.

Moisescu, Cristian, (2001),Arhitectura Românească Veche, Meridiane, Bucureşti. 
Musicescu, Ana Maria , Ionescu, Grigore, (1976),Biserica Domnească din Curtea de Argeş, Meridiane, Bucureşti.

Oprescu, Carmen, (2007), Arta feudală pe teritoriile româneşti, Ars Docendi, Bucureşti.

http://www.catacombeleortodoxiei.ro/index.php/artaortodoxa/133-arhiva-revistei/cuprins/1162-arta ortodoxanr-02). 